\title{
The determinants of MNC subsidiary initiatives implications for small business
}

\author{
Cher-Hung Tseng*
}

Department of Business Administration, National Pingtung Institute of Commerce, 51 Min Sheng E. Road, Pingtung 900, Taiwan, ROC

E-mail: chtseng@npic.edu.tw

*Corresponding author

\section{Cher-Min Fong}

Department of Business Administration,

National Sun Yat-Sen University,

Kaoshiung, Taiwan, ROC

E-mail: cmFong@bm.nsysu.edu.tw

\section{Kuo-Hsien Su}

Department of Sociology, National Taiwan University, Taipei, Taiwan, ROC

E-mail:khsu@ntu.edu.tw

\begin{abstract}
Since the importance of the subsidiary's role continues to increase, a growing number of studies have focused on MNC subsidiary strategies. The aim of this study is to explore the determinants of a subsidiary's initiative. Based on the subsidiary research's classification provided by Birkinshaw and Hood, an integrated framework is developed to examine the influences of three groups of variables on the subsidiary initiative, namely, the headquarters-subsidiary relationship, the subsidiary resources and the network characteristics of the subsidiary. Since previous studies have focused on subsidiary initiatives in developed countries, this study addresses the issue of MNC subsidiaries in developing countries. The present analysis of 67 European, US and Japanese MNC subsidiaries in Taiwan reveals that each of the three groups of variables influences the subsidiary initiative. Furthermore, in terms of individual variables, it is determined that procedural justice, a subsidiary's relative capabilities, and a subsidiary's local responsiveness all have a positive influence on the subsidiary initiative. Finally, because innovation is critical to small business's global strategy, this study discusses the implications of subsidiary initiatives for global strategy of small business and indicates potential directions for future research.
\end{abstract}

Keywords: MNC network; MNC subsidiary; subsidiary initiatives.

Reference to this paper should be made as follows: Tseng, C.-H., Fong, C.-M. and $\mathrm{Su}, \mathrm{K} . \mathrm{-H}$. (2004) 'The determinants of MNC subsidiary initiatives implications for small business', Int. J. Globalisation and Small Business, Vol. 1, No. 1, pp.92-114. 
Biographical notes: Cher-Hung Tseng is an Assistant Professor at the Department of Business Administration, National Pingtung Institute of Commerce, Pingtung, Taiwan ROC. He received his $\mathrm{PhD}$ in management from National Sun Yat-Sen University. His research interests include strategic alliances, entry strategy and initiatives of multinational corporation subsidiaries.

Cher-Ming Fong is an Associate Professor at the Department of Business Administration, National Sun Yat-Sen University, Kaoshiung, Taiwan ROC. $\mathrm{He}$ earned his PhD in strategic management at University of Maryland, College Park. He is also a Management Consultant for many Taiwanese enterprises. His current research interests include top management team, performance of venture capital and strategic alliances.

Kuo-Hsien $\mathrm{Su}$ is an Associate Professor at the Department of Sociology, National Taiwan University, Taipei, Taiwan ROC. He earned his PhD in sociology at Columbia University. His current research interests include social network and Chinese business groups.

\section{Introduction}

In recent years, multinational corporations (MNCs) have played an increasingly important role within the global economy. The value chain activities and assets of MNCs are geographically distributed around the world. Additionally, there are increasing number of resource transfers in the MNC. These resource transfers include components, semi-finished goods, individuals, and knowledge (Gupta and Govindarajan, 1991, 1994, 2000). Therefore, today's MNCs can be regarded as network organisations within which a variety of transactions take place (Ghoshal and Bartlett, 1990; Ghoshal and Nohria, 1989; Birkinshaw and Fry, 1998).

The MNC is no longer an organisation of similar subunits. In fact, it deliberately incorporates subsidiaries of different types in order to improve its competitiveness (Ghoshal and Bartlett, 1990; Frost, 2001). The differences between individual subsidiaries might arise from the particular location advantages of their host countries (Dunning, 1988; Dunning, 1995) and from industrial clusters (Porter, 1990). In other words, only by conducting research at the subsidiary level is it possible to fully determine the determinants of the MNC's success. However, previous studies have focussed on the MNC as a whole, rather than at its subsidiaries' level (Stopford and Wells, 1972; Egelhoff, 1982; Perlmutter, 1969; Prahalad and Doz, 1981). As asserted by Gupta and Govindrajan (1991), research performed at the MNC level is unable to identify the distinctiveness of each individual subsidiary or to recognise the particular contribution it makes.

Due to the limitations of previous studies, an increasing number of scholars have conducted research at the subsidiary level (Gupta and Govindarajan, 1994; Birkinshaw and Morrision, 1995; Birkinshaw, 1998). Studies relating to subsidiary level issues include the role of the subsidiary (Jarillo and Martinez, 1990; Taggart, 1998), the control mechanisms of a subsidiary (Nobel and Birkinshaw, 1998) and subsidiary performance (Birkinshaw and Morrision, 1995; Christmann, Day and Yip, 1999). Of the various subsidiary level aspects, the issue of subsidiary initiative is gradually attracting more 
attention since it provides a clear indication of the distinct contribution made to the MNC by the subsidiary (Roth and Morrison, 1992; Birkinshaw, 1997; Birkinshaw, Hood and Jonsson, 1998; Pearce, 1999; Delany, 2000). According to Birkinshaw (1997) and Birkinshaw, Hood and Jonsson (1998), the subsidiary initiative represents an entrepreneurial process in which a subsidiary exhibits, exploits and explores resources in order to respond to opportunities. The subsidiary initiative is not dictated by the MNC headquarters (HQ), but is initiated by the subsidiary itself. The subsidiary initiative is manifested in product modifications, new product development, innovations of the manufacturing process, acquiring MNC investment projects, innovations of marketing and organisational processes, and so on. For example, Philips's subsidiary in Taiwan has evolved into the critical centre of this MNC's computer, semiconductor, and monitor business.

As mentioned previously, an MNC comprises various subsidiaries that can make specific contributions to MNC's competitiveness. Especially in the context of highly global competition, an MNC must leverage its dispersed assets embedded in each subsidiary in order to gain competitiveness (Birkinshaw, 1997). However, due to some factors, such as the MNC's control on the subsidiary and the dependence of the subsidiary on the MNC's resources, it is not easy for a subsidiary to launch an initiative. Therefore, it is important to explore the topic why some subsidiaries can exhibit more initiatives than other subsidiaries.

The main objective of this paper is to investigate the determinants of MNC subsidiary initiative. Although many previous studies have considered the subsidiary initiative, some researchers have stated that there is merit in further exploring the relative influences of certain constructs on the subsidiary initiative (Birkinshaw, Hood and Jonsson, 1998). Based on the factors of the framework proposed by Birkinshaw and Hood (1998), we present an integrated framework including three groups of variables, which affect the subsidiary initiative. This framework is composed of three important perspectives of MNC subsidiary research. Hence, we believe this framework can provide a basis for examining the subsidiary initiative. In addition, most previous studies have targeted subsidiaries in fully developed countries such as Canada, Sweden and the UK. Some researchers have suggested the need to conduct similar research in developing countries if the contributions made by subsidiaries are to be fully understood (Birkinshaw, Hood and Jonsson, 1998).

Finally, owing to the increasing number of small businesses entering the foreign markets, it is crucial to understand the globalisation strategy used by small businesses. This research has two points relating to the globalisation strategy of small business. First, the scale of the MNC subsidiary is usually not so large. The average number of employees in the research sample is less than 500 , so it is reasonable to relate the management topics of subsidiary to those of small business. Second, this paper focusses on the subsidiary initiatives (that is, innovation topic), which is also important for small business to be successful in the foreign markets since a small firm usually pursues a niche strategy based on 'innovation'. Therefore, this study also discusses the implications of the proposed framework on the globalisation strategy of small business, especially in the innovation topic. 


\section{Literature review and hypotheses}

\subsection{Research perspectives of subsidiary initiative and theoretical framework}

Adopting Birkinshaw and Hood's classification (Birkinshaw and Hood, 1998b) of subsidiary research, this study hypothesises that three groups of variables influence the subsidiary initiative, namely the HQ-subsidiary relationship, the subsidiary resources and the network characteristics of the subsidiary within the MNC network. Birkinshaw and Hood (1998b) strongly asserted that these variables provide a valuable means of understanding subsidiary behaviours. Moreover, they asserted that these groups are not independent, but that they actually complement each another. The three groups are explained as follows:

- HQ-subsidiary relationship characteristics: Although the MNC network perspective provides a valuable means of exploring different MNC behaviours, Birkinshaw and Hood (1998) asserted that the influence of the HQ on the subsidiary cannot be neglected since the HQ-subsidiary relationship is the most crucial link in the MNC network. Because the HQ holds the subsidiary's equity and, hence, has the power of influencing the subsidiary, including appointing important staff, transferring resources and so on. This study adopts two variables to represent the characteristics of the HQ-subsidiary relationship, namely, whether or not the HQ appoints an expatriate as the CEO of the subsidiary, and the degree of procedural justice between the HQ and the subsidiary.

- Subsidiary resource characteristics: This group of variables stresses the effects of resources of a subsidiary upon its behaviour. Unlike the influence from the HQ, this group presents that the subsidiary can possess and develop its own resources and capabilities in order to enhance its value and performance. Using this group of variables, this study explores the influences of the scope of value-chain activities performed by a subsidiary and its relative capabilities on the subsidiary initiative.

- Network characteristics of the subsidiary within the MNC network ${ }^{1}$ : Birkinshaw and Hood (1998b) asserted that the MNC network perspective regards subsidiaries as entities embedded within the MNC network, and considers the behaviour of each subsidiary to be influenced by its particular position within the network. In this perspective, Birkinshaw and Hood (1998b) emphasised the role played by the subsidiary within the MNC network. The subsidiary's role is defined in terms of the position it occupies within the MNC network, that is, the subsidiary's integration with MNC, the subsidiary's local responsiveness, and the non-substitutability of the subsidiary within the MNC network.

From the classification, the present study proposes the integrated framework presented in Figure 1. 
Figure 1 Theoretical framework Change

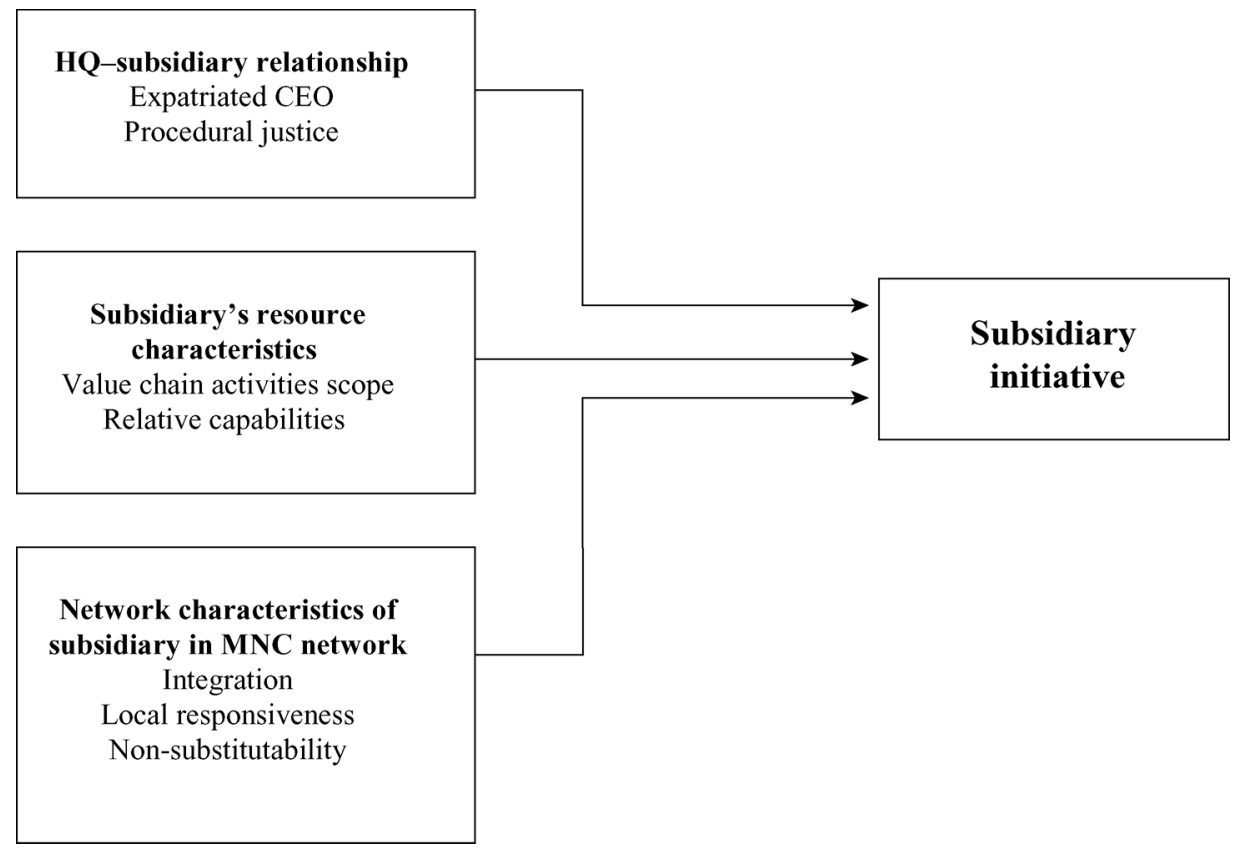

\subsection{Hypotheses development}

\subsubsection{Influence of HQ-subsidiary relationship characteristics}

This section discusses the influence of the HQ-subsidiary relationship upon the subsidiary initiative. Two individual variables are considered, namely whether or not the HQ appoints an expatriate as the CEO of the subsidiary, and the degree of procedural justice between the HQ and the subsidiary.

\subsubsection{Influence of an expatriate as the subsidiary's CEO}

The appointment of an expatriate as the CEO of a subsidiary has a significant impact upon the subsidiary initiative due to inherent cultural differences between the CEO and his local staff, and due to differences in his motivation and ability to participate in local systems. Hennart (1993) asserted that MNCs will struggle to exert cultural control on its subsidiaries due to cultural differences. When an expatriate is appointed as the CEO of a remote subsidiary, the cultural interface is transferred from the HQ to the subsidiary itself. This transfer can theoretically enhance MNCs' cultural control, but it also increases the potential cultural friction between the expatriate and local staff. Moreover, it may also serve to reduce the motivation of the subsidiary's local management teams, particularly if the expatriated CEO is provided with a higher salary and enhanced benefits. In this situation, it is likely that the subsidiary initiative will be decreased.

Additionally, Zaheer and Mosakowski (1997) contended that social and cultural barriers tend to limit the ability of the subsidiary to participate in local knowledge-sharing communities. Since a national native generally enjoys closer 
relationships with local suppliers, distributors, and governmental and research institutions, MNCs may choose to overcome the liability of foreignness by appointing a local executive to the position of CEO (Zaheer and Mosakowski, 1997). This enables these critical local relationships to be maintained, hence securing strategic location advantages and increasing the subsidiary initiative. Accordingly, the present study proposes the following hypothesis:

H1-1: The expatriated CEO of the subsidiary is negatively related to the subsidiary initiative.

\subsubsection{Influence of procedural justice between the $H Q$ and its subsidiary}

According to Kim and Mauborgne (1993a; 1993b) the degree of procedural justice between the HQ and its subsidiary is defined as: the extent of two-way interactions between the HQ and the subsidiary; whether or not the HQ treats each subsidiary equally; whether or not the subsidiary is free to challenge the views of the HQ; whether or not the HQ fully considers the particular situation of each subsidiary in its decision-making processes; and finally, whether or not the HQ truly understands each subsidiary's particular circumstances. In this study, it is argued that some characteristics of procedural justice are related to the facilitating conditions for subsidiary initiative.

Firstly, interactions between the HQ and its subsidiary increase the subsidiary initiative. Ghoshal and Bartlett (1988) asserted that interactions reflect the extent of organisational integration and are conducive to reconciling different perspectives and to stimulating innovations. Russell (1999) also argued that the exchange of information and communication within organisations are both effective in promoting entrepreneurial behaviour.

Secondly, the action of a subsidiary challenging the HQ can in itself enhance the subsidiary initiative. Within an environment of permissible challenge, the subsidiary initiative will be recognised by the HQ and will not be influenced by the corporate immune system. In other words, where a high degree of procedural justice exists, the HQ permits its subsidiaries to challenge its own views, and will take the risk of accepting bad initiatives rather than rejecting excellent ones (Birkinshaw, 1997; Birkinshaw and Ridderstrale, 1999). Furthermore, the ability of subsidiaries to challenge the HQ creates a restless, self-questioning atmosphere throughout the MNC, which satisfies the objective of strategic renewal, including its innovations (Kim and Mauborgne, 1993a; Kim and Mauborgne, 1993b).

Thirdly, higher procedural justice increases the level of the subsidiary's commitment. The various aspects of procedural justice are related to the attitudes of commitment, trust and harmony (Kim and Mauborgne, 1993a; Kim and Mauborgne, 1993b) and these attitudes represent the perquisites for innovation (Damanpour, 1991). Since an organisation must adopt a long-term perspective when evaluating high-risk investments, a subsidiary is more likely to generate new initiatives when the degree of procedural justice is higher. Based upon the above arguments, this study proposes the following hypothesis:

H1-2: The level of procedural justice between the HQ and a subsidiary is positively related to the subsidiary initiative. 


\subsubsection{Influence of characteristics of a subsidiary's resources}

This section introduces the second group of variables, namely, the characteristics of a subsidiary's resources. These characteristics are explored in terms of the scope of value-chain activities performed by the subsidiary and the capabilities of the subsidiary compared to those of other subsidiaries.

\subsubsection{Influence of the scope of a subsidiary's value chain activities ${ }^{2}$}

The concurrent execution of various value-chain activities by a subsidiary promotes the impetus toward innovation. For instance, an active cooperation between the marketing division and the $R \& D$ division ensures that $R \& D$ efforts are directed towards satisfying the very latest consumer requirements. Similarly, the R\&D division must cooperate with the manufacturing division to improve manufacturing processes. Hence, when a subsidiary performs two or more business activities concurrently, it creates an opportunity to generate new ideas. Moreover, Roth and Morrison (1992) asserted that when the MNC have the dispersed type of resource configuration, that is, the subsidiary conducts various value-chain activities by itself, it would enhance the subsidiary's innovation. Hence, this study proposes the following hypothesis:

H2-1: The scope of a subsidiary's value-chain activities is positively related to the subsidiary initiative.

\subsubsection{Influence of the capabilities of a subsidiary relative to those of other subsidiaries}

Capabilities are defined as the organisation's ability to integrate, build and reconfigure internal and external competence to address rapidly changing environments (Teece, Pisano and Shuen, 1997). In this study, the subsidiary's capabilities indicate the capabilities relative to those of other subsidiaries. These capabilities include the fields of R\&D, manufacturing, marketing and management systems and so on. Through enhancing its capabilities, a subsidiary is better able to identify and implement innovative opportunities, hence establishing its credibility and improving its initiative.

The extent of a subsidiary's capabilities has a direct influence upon its ability to identify and implement new opportunities. Ghoshal and Bartlett (1988) argued that when resources are concentrated in the HQ, the innovations adopted by a subsidiary are generally those originating from the HQ. This tends to reduce the motivation and, indeed, the necessity for a subsidiary to launch initiatives independently. Moreover, when a subsidiary is in possession of affluent resources, it can afford to absorb the high risks and costs of an innovation project (Damanpour, 1991; Woodman, Sawyer and Griffin, 1993; Glynn, 1996). Additionally, relatively high capabilities afford the subsidiary the luxury of adopting a trial-and-error approach, which clearly has a positive impact on the level of the subsidiary initiative.

Furthermore, the accumulation of various capabilities enhances the credibility of the subsidiary. Birkinshaw (1997) stated that when the subsidiary's capabilities are recognised by the HQ, its credibility as a source of innovation is enhanced. Roth and Morrison (1992) also contended that the HQ will assign a greater degree of responsibility to subsidiaries that demonstrate a broader range of capabilities, hence enabling these 
subsidiaries to attain a greater initiative level. Accordingly, the present study proposes the following hypothesis:

H2-2: The relative capabilities of a subsidiary compared to those of other subsidiaries are positively related to the level of subsidiary initiative.

\subsubsection{Influence of network characteristics of a subsidiary in the MNC network}

This section examines the network characteristics of a subsidiary in the MNC network in terms of its integration with the $\mathrm{MNC}$, its local responsiveness and its degree of non-substitutability.

\subsubsection{Influence of a subsidiary's integration with $M N C$}

There are two rationales that the subsidiary' integration with MNC will increase its initiative. The first reason is the integration would enhance the opportunities of finding new innovative ideas, and the second reason is that the integration would increase the subsidiary's utilisation of resources. These reasons are stated as follows:

Firstly, the extent of integration between a subsidiary and the other MNC units has a major influence upon its ability to identify new business opportunities. When a subsidiary has a high level of integration with other MNC units, it is exposed to the vast information resources and entrepreneurial opportunities of the entire MNC network (Tsai and Ghoshal, 1998). Furthermore, Floyd and Wooldridge (1999) claim that when the centrality of a subsidiary in the MNC is high, that is, it has a greater integration with the MNC units than its sister subsidiaries have, it benefits from a higher degree of knowledge exchange, which tends to promote its entrepreneurial behaviour.

Secondly, the links of a subsidiary to the other MNC units also affects its utilisation of resources. Many researchers have argued that links between different organisations have an impact on resource sharing and utilisation (Tsai and Ghoshal, 1998; Goes and Park, 1997). Hedlund and Rolander (1990) also emphasised the importance of links among MNC subunits in exploiting and exploring resources to achieve MNC's objectives, including those relating to innovations. Accordingly, this study proposes the following hypothesis:

H3-1: The degree of integration between the MNC and the subsidiary is positively related to the subsidiary initiative.

\subsubsection{Influence of a subsidiary's local responsiveness}

As the rationale presented in H3-1, when a subsidiary's local responsiveness increases,that is, its links to the local stakeholders increase, the subsidiary is likely to enjoy greater entrepreneurial opportunities and will be able to utilise more resources from the host country.

Many researchers have emphasised the importance of the advantages of location (Frost, 2001; Dunning, 1988; Dunning, 1995). The advantages of location have a significant impact upon many aspects of the subsidiary's behaviour, including its innovations. Rugman and Verbeke (2001) stressed the influence of a subsidiary's embeddedness in the host country on its innovations. They asserted that the evolution of knowledge of a host country is path-dependent, that is, each country's path is idiosyncratic and is formulated by the various institutional and contextual factors of that country, including its government's technology and industrial policies, and the 
interactions among enterprises and institutions, business networks and universities. It is extremely difficult to replicate each country's idiosyncratic path, and the benefits of this path can only be absorbed by the local subsidiary itself rather than by other subsidiaries. Furthermore, the links between a subsidiary and its local stakeholders can neither be established nor fully appreciated by the HQ or by any of its other subsidiaries (Holm, Johanson and Thilenius, 1995). Hence, when a subsidiary has more integrated links with its local stakeholders, it can use the location advantages exclusively and then its initiative will be increased.

Additionally, when a subsidiary's local responsiveness increases, it becomes exposed to a heterogeneous local environment containing different types of markets and customers, and hence enjoys a greater number of distinct opportunities and stimuli (Zahra, 1991). Furthermore, using the rationale of H3-1, the links between a subsidiary and its local stakeholders enhance the mobilisation and utilisation of its resources, which, in turn, increases the implementation of subsidiary initiative. Accordingly, this study proposes the following hypothesis:

H3-2: The extent of a subsidiary's local responsiveness is positively related to the subsidiary initiative.

\subsubsection{Influence of a subsidiary's non-substitutability by other subsidiaries}

The definition of a subsidiary's non-substitutability is the extent to which its functions and activities cannot be replaced by other subsidiaries. For example, when other subsidiaries produce the same products or share the same marketplaces as the focal subsidiary, these subsidiaries could replace the focal subsidiary. When the focal subsidiary has a high degree of non-substitutability, its level of subsidiary initiative will be higher since it is the only subsidiary having the necessary resources and capabilities required to perform a particular activity (Moore and Birkinshaw, 1998). Andersson and Pahlberg (1997) asserted that the non-substitutability of a focal subsidiary will increase its influence on other subsidiaries, including their technological developments and innovations. Moreover, from the network perspective (Burt, 1992) it is argued that a higher structural equivalence indicates that the subsidiary has the same input and output transaction targets as the other subsidiaries in the MNC network. This means that the focal subsidiary has a lower level of non-substitutability in the MNC. Under this circumstance, other subsidiaries may well be in possession of the same information, opportunities and ability to mobilise resources as the focal subsidiary, and thus it may struggle to generate its own distinct innovative ideas. Clearly, the focal subsidiary initiative will then decrease. Accordingly, this study proposes the following hypothesis:

H3-3: The degree of a subsidiary's non-substitutability by other subsidiaries in the MNC network is positively related to the subsidiary initiative.

Therefore, based on the previous statement, a framework is proposed to explore the determinants of the subsidiary initiative. More specifically, a non-expatriate CEO of the subsidiary, the level of procedural justice between the subsidiary and the HQ, the scope of the subsidiary's value chain activities, the subsidiary's relative capability, the subsidiary's integration with the MNC, the subsidiary's local responsiveness in the host country and the subsidiary's non-substitutability are positives associated with the subsidiary initiative. 


\section{Research methodology}

\subsection{Data collection}

This study focusses upon MNC subsidiaries operating in Taiwan. The definition of the MNC subsidiary in Taiwan is that the foreign enterprise controls more than $50 \%$ of the subsidiary's equity. This definition is consistent with that adopted by previous researchers, for example, Jarillo and Martinez, 1990; Taggart, 1998, 1997. The main attribute of this definition is that when the HQ owns more than $50 \%$ of the equity of the subsidiary, it maintains overall responsibility for the subsidiary's operation. Conversely, if its share is less than $50 \%$, the HQ will be dominated by its partner, and hence this type of subsidiary falls outside the scope of the present study.

The subsidiaries considered in the present study were drawn from the manufacturing and non-financial service industries in Taiwan. The source of the sampling frame was Foreign Enterprises in Taiwan - 2000, published by Dun and Bradstreet Information Services. It was decided that only subsidiaries of a certain scale and period in operation should be considered. Specifically, the present sample was constrained to subsidiaries with greater than 30 employees and which had been in operation for longer than one year.

Following a review of related studies, a preliminary questionnaire was drafted and its content and clarity reviewed in the context of interviews with four MNC subsidiary managers. Having modified the questionnaire accordingly, questionnaires were mailed to 195 subsidiaries whose managers had consented to participate in the study. Following two follow-up initiatives, 78 completed questionnaires were returned, of which 11 were rejected on the grounds of insufficient data or because the subsidiary failed to meet the current sampling requirements. The 67 valid questionnaires represented a return rate of $34.36 \%$. Appendix 1 displays the basic characteristics of the research sample.

In order to ensure the validity of the variables considered in the present research, reference was made to previous studies of subsidiary-related variable measurement, and two rounds of pre-testing were conducted. The Cronbach $\alpha$ indicator was adopted to verify the reliability of the variables. The corresponding Cronbach $\alpha$ values for each variable are listed in Appendix 2. All research variables have a value greater than 0.7, and hence, according to the criteria specified by Nually (1978) have a high level of reliability.

\subsection{Measurement of research variables}

Table 1 illustrates the relevant studies and corresponding measurements of each of the variables. The 7-point Likert scale was employed to measure the continuous variables and to aggregate their individual items in order to represent their overall value. This scale varies from strong agreement to strong disagreement, or from a highest level to a lowest level. Meanwhile, dummy variables were used to represent the non-continuous variables, for example, whether or not the HQ appoints an expatriate as the subsidiary's CEO, or the scope of the subsidiary value chain activities.

Dummy variables were also used to measure the following control variables: MNC nationalities (Europe, US or Japan), whether or not the subsidiary conducts a manufacturing activity, and the subsidiary industry type. The scale of each subsidiary was measured by asking each respondent to use the 7-point Likert scale to compare the relative scale of their subsidiary to that of other subsidiaries. The subsidiary's operation time was quantified as the number of years between its date of establishment and the year 
2000. The MNC's equity control of the subsidiary was expressed by the percentage of the subsidiary's total equity held by the MNC. The global integration of the subsidiary's industry was measured using the 7-point Likert-scale. The relevant descriptive statistics, correlation coefficients, and research variable reliabilities are illustrated in the Appendix. All of the correlation coefficients are less than 0.5. Moreover, the largest VIF (variance inflation factor) of the regression model listed in Table 1 is 2.383 , which falls well below the level of 10 suggested by Hair et al. (1995). Hence, multi-colinearity is not a serious issue in the present model. Finally, the multiple-regression was used to examine the influences of the independent variables on the subsidiary initiative. Where the independent variables were binary, dummy variables were used to analyze their effects on the subsidiary initiative.

Table 1 The measurement of research variables

\begin{tabular}{|c|c|c|}
\hline Variables & Measurement items & Related studies \\
\hline Subsidiary initiative & $\begin{array}{l}\text { - The subsidiary is always the first to obtain } \\
\text { MNC's new international activities } \\
\text { - The level of subsidiary initiative compared } \\
\text { to other subsidiaries' ones in MNC } \\
\text { - The level of subsidiary initiative compared to } \\
\text { other competitors' ones } \\
\text { - The extent to which the subsidiary modifies its } \\
\text { products } \\
\text { - The likelihood of the subsidiary applying for } \\
\text { MNC's new projects } \\
\text { - The extent to which the subsidiary creates } \\
\text { new resources, technologies, products and } \\
\text { knowledge }\end{array}$ & $\begin{array}{l}\text { (Roth and } \\
\text { Morrison, 1992; } \\
\text { Birkinshaw, 1997; } \\
\text { Birkinshaw, Hood } \\
\text { and Jonsson, 1998) }\end{array}$ \\
\hline $\begin{array}{l}\text { Whether or not an HQ } \\
\text { appoints an expatriate as } \\
\text { the subsidiary's CEO }\end{array}$ & $\begin{array}{l}\text { - A dummy variable was used to indicate } \\
\text { the two types of CEO: when the subsidiary } \\
\text { CEO is an expatriate from the HQ, the dummy } \\
\text { variable is coded as } 0 \text {, and when the subsidiary } \\
\text { CEO is a local person, the dummy value } \\
\text { is coded as } 1 \text {. }\end{array}$ & \\
\hline $\begin{array}{l}\text { Procedural justice } \\
\text { between the HQ and its } \\
\text { subsidiary }\end{array}$ & $\begin{array}{l}\text { - There are a great deal of communications } \\
\text { between HQ and subsidiary } \\
\text { - HQ uses a consistent decision making process } \\
\text { among subsidiaries } \\
\text { - Subsidiary managers can challenge and reject } \\
\text { HQ's viewpoints } \\
\text { - The extent to which HQ understand local } \\
\text { market when HQ involves a decision } \\
\text { relating to subsidiary }\end{array}$ & $\begin{array}{l}\text { (Kim and } \\
\text { Mauborgne, 1993a; } \\
\text { Kim and } \\
\text { Mauborgne, 1993b) }\end{array}$ \\
\hline $\begin{array}{l}\text { Scope of a subsidiary's } \\
\text { value chain activities }\end{array}$ & $\begin{array}{l}\text { Whether or not the subsidiary conducts } \\
\text { two or more value chain activities, including } \\
\text { manufacturing, marketing including sales } \\
\text { and logistic distribution and R\&D. We } \\
\text { code this variable as } 0 \text { when the subsidiary } \\
\text { has two or more value chain activities; } \\
\text { when it has only one value chain activity, } \\
\text { it is coded as } 1 \text {. }\end{array}$ & $\begin{array}{l}\text { (Roth and } \\
\text { Morrison, 1992) }\end{array}$ \\
\hline
\end{tabular}


Table 1 The measurement of research variables (Continued)

\begin{tabular}{|c|c|c|}
\hline Variables & Measurement items & Related studies \\
\hline $\begin{array}{l}\text { Capabilities of the } \\
\text { subsidiary relative to } \\
\text { those of other } \\
\text { subsidiaries }\end{array}$ & $\begin{array}{l}\text { The level of R\&D capability of the subsidiary } \\
\text { relative to that of other subsidiaries } \\
\text { - The level of manufacturing capability of the } \\
\text { subsidiary relative to that of other subsidiaries } \\
\text { - The level of marketing capability of the } \\
\text { subsidiary relative to that of other subsidiaries } \\
\text { - The level of management capability of the } \\
\text { subsidiary relative to that of other subsidiaries } \\
\text { - The level of innovation capability of the } \\
\text { subsidiary relative to that of other subsidiaries }\end{array}$ & $\begin{array}{l}\text { (Roth and } \\
\text { Morrison, 1992; } \\
\text { Birkinshaw, Hood } \\
\text { and Jonsson, 1998) }\end{array}$ \\
\hline $\begin{array}{l}\text { Extent of a subsidiary's } \\
\text { integration with MNC }\end{array}$ & $\begin{array}{l}\text { - The level of purchasing integration and } \\
\text { coordination between MNC and subsidiary } \\
\text { - The level of manufacturing integration and } \\
\text { coordination between MNC and subsidiary } \\
\text { - The level of R\&D integration and coordination } \\
\text { between MNC and subsidiary } \\
\text { - The level of marketing integration and } \\
\text { coordination between MNC and subsidiary } \\
\text { - The level of future strategy integration and } \\
\text { coordination between MNC and subsidiary }\end{array}$ & $\begin{array}{l}\text { (Jarillo and } \\
\text { Martinez, 1990; } \\
\text { Taggart, 1998, } \\
\text { 1997; Roth and } \\
\text { Morrison, 1990) }\end{array}$ \\
\hline $\begin{array}{l}\text { Level of subsidiary's } \\
\text { local responsiveness }\end{array}$ & $\begin{array}{l}\text { - The level of the subsidiary's response to } \\
\text { local community's requirements } \\
\text { - The level of the subsidiary's response to } \\
\text { host government's requirements } \\
\text { - The level the subsidiary's response to local } \\
\text { consumer's requirements } \\
\text { - The extent to which the subsidiary interacts } \\
\text { with local firms } \\
\text { - The extent to which the subsidiary interacts } \\
\text { with host governments, research and other } \\
\text { institutions }\end{array}$ & $\begin{array}{l}\text { (Jarillo and } \\
\text { Martinez, 1990; } \\
\text { Taggart, 1998, } \\
\text { 1997; Hannon, } \\
\text { Huang and Jaw, } \\
\text { 1995) }\end{array}$ \\
\hline $\begin{array}{l}\text { Level of subsidiary's } \\
\text { non-substitutability by } \\
\text { other subsidiaries }\end{array}$ & $\begin{array}{l}\text { - The extent to which the subsidiary frequently } \\
\text { competes with other subsidiaries in products, } \\
\text { markets and performed activities. } \\
\text { - The extent to which other MNC subsidiaries' } \\
\text { activities and functions are the same as the } \\
\text { subsidiary's activities and functions } \\
\text { - The extent to which the subsidiary's activities } \\
\text { and functions can be replaced immediately by } \\
\text { other subsidiaries' activities and functions } \\
\text { - The number of subsidiaries that have the potential } \\
\text { to replace the subsidiary's functions and activities }\end{array}$ & $\begin{array}{l}\text { This concept is } \\
\text { generated form } \\
\text { (Andersson and } \\
\text { Pahlberg, 1997; } \\
\text { Astley and Zajac, } \\
\text { 1990) }\end{array}$ \\
\hline
\end{tabular}


Table 1 The measurement of research variables (Continued)

\begin{tabular}{llc}
\hline Variables & \multicolumn{1}{c}{ Measurement items } & Related studies \\
\hline Level of industry global & - The level of intensity of global competition & (Birkinshaw, Hood \\
integration & - The extent to which companies must & and Jonsson, 1998) \\
& deploy global resource network to complete & \\
& successfully & \\
- The extent to which the products are & homogenous worldwide \\
- New product introductions occur in all & major markets simultaneously \\
& - The extent to which business activities are \\
& influenced by global scale economies \\
\hline
\end{tabular}

\section{Research findings and discussion}

\subsection{Effects of each of the three group variables on the subsidiary initiative}

This study aims to explore the relative influences of three groups of variables on the subsidiary initiative, namely the HQ-subsidiary relationship, the subsidiary resources, and the network characteristics of the subsidiary. As shown in Table 2, the three groups of variables exhibit significance levels of $0.001,0.000$, and 0.000 , respectively. These results indicate that each of the three groups has a significant impact on the subsidiary initiative. Additionally, an inspection of the final column in Table 2 indicates that compared with the reduced models (incorporating only one group of variables), the full models (incorporating all three groups of variables) have greater explanatory powers regarding the subsidiary initiative, and that the significance levels of the increased $\mathrm{R}^{2}$ are $0.000,0.012$ and 0.000 , respectively. Consequently, all three groups of variables must be considered if the subsidiary initiative is to be fully comprehended. These results confirm the importance of establishing an integrated framework when establishing the determinants of the subsidiary initiative.

Table 2 The explanatory power of individual group on subsidiary initiative

\begin{tabular}{|c|c|c|c|c|}
\hline Individual group & $\begin{array}{l}\text { Individual } \\
\text { Group } R^{2 a}\end{array}$ & $\begin{array}{l}\text { The Significance of } \\
\text { Individual Group }\end{array}$ & $\begin{array}{l}\text { The Increased } R^{2} \\
\text { of Full Model }\end{array}$ & $\begin{array}{l}\text { The Significance } \\
\text { of Increased } R^{2}\end{array}$ \\
\hline $\begin{array}{l}\text { HQ-subsidiary } \\
\text { relationships } \\
\text { characteristics }\end{array}$ & $18.3 \%$ & 0.001 & $28.3 \%$ & 0.000 \\
\hline $\begin{array}{l}\text { Characteristics of a } \\
\text { subsidiary's resources }\end{array}$ & $34.4 \%$ & 0.000 & $12.2 \%$ & 0.012 \\
\hline $\begin{array}{l}\text { Network characteristics } \\
\text { of a subsidiary in the } \\
\text { MNC }\end{array}$ & $26.6 \%$ & 0.000 & $20.0 \%$ & 0.000 \\
\hline
\end{tabular}

Notes: $\quad{ }^{a}$ compared with model with only control variables incorporated

${ }^{b}$ the difference of $\mathrm{R}^{2}$ between full model, model with three groups of variables and reduced model, model with one group of variables 


\subsection{Results of hypotheses}

This section discusses the testing results of the current research hypotheses. As indicated in the regression model presented in Table 3, whether or not the HQ appoints an expatriate as the subsidiary's CEO is not significant, and hence HI-l is not supported. This observation may well be grounded in the particular characteristics of Taiwan. In Taiwan, expatriate CEOs of MNC subsidiaries are generally regarded as opinion leaders due to the expertise and experience they have gained in more developed countries. These CEOs are always afforded particular respect by the government and by local business leaders alike. Hence, their participation in local business systems may attain the same degree as that of local CEOs. Additionally, reward systems in the MNC subsidiary may be highly formalised. Therefore, an expatriate CEO may have no greater motivations than a local CEO for launching new subsidiary initiatives.

Table 3 The regression model

\begin{tabular}{|c|c|c|c|c|c|c|}
\hline Variable & Coefficient & $\begin{array}{l}\text { Coefficient } \\
\text { Significance }\end{array}$ & $V I F$ & $R^{2}$ & $\begin{array}{c}\text { Model } \\
\text { Significance }\end{array}$ & $\begin{array}{l}D-W \\
\text { Test }\end{array}$ \\
\hline \multicolumn{7}{|l|}{ Control variables } \\
\hline - Industry integration & -0.054 & 0.645 & 1.842 & $62.40 \%$ & 0.000 & 1.993 \\
\hline - Industry type & 0.132 & 0.213 & 1.490 & & & \\
\hline - Manufacturing function & -0.066 & 0.577 & 1.862 & $51.40 \%$ & & \\
\hline - Subsidiary age & 0.064 & 0.515 & 1.312 & adjusted & & \\
\hline - Subsidiary scale & 0.086 & 0.367 & 1.208 & & & \\
\hline - Nationality - US & -0.070 & 0.604 & 2.428 & & & \\
\hline - Nationality - Japan & -0.033 & 0.801 & 2.262 & & & \\
\hline - HQ control equity & 0.111 & 0.289 & 1.458 & & & \\
\hline \multicolumn{7}{|l|}{$H Q-$ subsidiary relationships } \\
\hline - Expatriated CEO & -0.174 & 0.116 & 1.606 & & & \\
\hline - Procedural justice & 0.214 & 0.053 & 1.584 & & & \\
\hline \multicolumn{7}{|l|}{ Subsidiary's resources } \\
\hline - Value-chain activities Scope & -0.083 & 0.426 & 1.444 & & & \\
\hline $\begin{array}{l}\text { - Subsidiary's relative } \\
\text { capabilities }\end{array}$ & 0.489 & 0.000 & 2.067 & & & \\
\hline \multicolumn{7}{|l|}{$\begin{array}{l}\text { Subsidiary's network } \\
\text { characteristics on MNC }\end{array}$} \\
\hline - Integration & -0.071 & 0.523 & 1.638 & & & \\
\hline - Local responsiveness & 0.268 & 0.026 & 1.865 & & & \\
\hline - Non-substitutability & -0.007 & 0.946 & 1.312 & & & \\
\hline
\end{tabular}

The results of the regression model support H1-2, that is, the greater the degree of procedural justice between the HQ and the subsidiary, the higher the subsidiary initiative. The standard coefficient is 0.214 and the significance level is 0.053 . Regarding $H 2-1$, the 
results indicate that the effect of the subsidiary's value chain scope is not significant, and hence the hypothesis is not supported. There are perhaps two reasons why this is the case. Firstly, although a broader scope of value-chain activities promotes innovation opportunities, most subsidiaries focus on specific value-chain activities, hence securing the advantages of specialisation and, therefore, prompting initiatives in this specific field. Accordingly, subsidiary initiatives occur with even a single value-chain activity. Secondly, when the scope of the value chain exceeds two or more activities, the subsidiary is obliged to establish coordination mechanisms to integrate the various activities. Without these linkage mechanisms, subsidiary initiative will not occur. It is acknowledged by the current researchers that these assertions must be confirmed through further study.

Hypothesis $H 2-2$ suggests that when a subsidiary possesses more capabilities than other subsidiaries, its level of subsidiary initiative will increase accordingly. The results of Table 3 support this hypothesis. The standard coefficient is 0.298 and the significance level is 0.005 .

Hypothesis $H 3-1$ asserts that a greater integration between the subsidiary and the MNC will enhance the subsidiary initiative. However, the results of Table 3 do not support this hypothesis. There may be three reasons why this is the case. Firstly, although a closer integration between the subsidiary and the MNC might suggest that the subsidiary will interact more frequently with other subsidiaries, the content of these interactions may be restricted solely to the coordination and integration of routine processes in the MNC. Hence, these interactions are unlike to become the sources of innovation. Secondly, as the level of integration among MNC subsidiaries increases, the HQ or leading subsidiary is obliged to implement coordination and integration processes. Consequently, even though the subsidiary takes part in a greater number of interactions with other subsidiaries, this does not ensure the generation of new subsidiary initiatives when its integration is controlled by the HQ or the leading subsidiary. Thirdly, H3-1 suggests that integrations stimulate the subsidiary to generate ideas for initiatives. However, since these integrations do not take place independently of other subsidiaries, the focal subsidiary is not the only unit to receive ideas for new initiatives. Birkinshaw (Birkinshaw, 1998) has argued that the MNC is actually an internally competitive market in which each of the subsidiaries competes for new projects. Therefore, the higher integration between the subsidiary and the MNC does not ensure the occurrence of subsidiary initiatives. Again, it is acknowledged that these assertions should be investigated further to confirm their validity.

Hypothesis H3-2 asserts that the level of a subsidiary's local responsiveness has a positive influence on the subsidiary initiative. The results of Table 3 support this hypothesis. The standard coefficient is 0.268 and the significance level is 0.026 .

Hypothesis $\mathrm{H3}-3$ asserts that where the likelihood of the subsidiary being replaced by other subsidiaries is higher, the level of the subsidiary initiative will be lower. However, the results presented in Table 3 do not support this hypothesis. It is possible that the insignificant influence of the subsidiary's non-substitutability can be attributed to the impact of structural equivalence. As argued previously in $H 3-3$, when other subsidiaries conduct similar functions and activities, the MNC subsidiaries are in possession of similar information, and consequently do not constitute unique sources of innovation. However, from the structural equivalence perspective, subsidiaries that share the same products and markets may be in competition with each other. Therefore, this particular 
structural equivalence situation might stimulate subsidiaries to launch their own initiatives in order to gain a competitive edge. This statement is consistent with Birkinshaw (1997) who argued that the MNC is actually an internal market in which the subsidiaries are in mutual competition. Competition among sister-subsidiaries is an important contributory factor towards the loss of subsidiaries' charters. Hence, the positive and negative effects of structural equivalence on the subsidiary initiative cause H3-3 not to be supported. However, it is recognised that this argument requires further study.

\section{Conclusions and future research directions}

This research intends to propose an integrated framework to examine the influences of three groups of variables on the subsidiary initiative, namely, the HQ-subsidiary relationship, the subsidiary resources, and the network characteristics of the subsidiary. The present empirical results confirm that all three perspectives have a significant influence. The results confirm the requirement for an integrated framework and the use of multi-perspectives in any exploration of subsidiary behaviour. The testing results of these hypotheses show that the subsidiary initiative is positively influenced by the degree of procedural justice between the HQ and the subsidiary, by the capabilities of the subsidiary relative to those of other subsidiaries, and by the local responsiveness of the subsidiary. These results are consistent with those of previous studies. In addition, these significant hypotheses have some implications.

First, the significance of procedural justice demonstrates that although many studies assert the importance of the MNC as a network organisation, the HQ-subsidiary dyadic relationship still remains a strongly influential link in the MNC (Birkinshaw and Hood, 1998a). Moreover, this finding would be more crucial for small business to be innovative. As for small business, the relationship between the HQ and the foreign affiliate is closer because the scare resource of the foreign affiliate makes it keep higher interaction with its HQ and hence the procedure justice becomes an important factor affecting the innovation of small business's subsidiary.

Second, the importance of a subsidiary's capabilities confirms that the resources of a subsidiary serve as a foundation for its initiatives, and enable it to establish its credibility and to generate opportunities for the identification and implementation of ideas. In addition, this result is also crucial for small business because when a firm's scale is small, it must develop its specific capability in order to be innovative

Third, the significance of a subsidiary's local responsiveness confirms that the location advantages of the host country can contribute greatly to the subsidiary initiative. These advantages can only be understood and secured by the local subsidiary itself. Therefore, in all host countries, the subsidiary must become an insider within local business networks (Andersson and Forsgren, 1996) if the MNC is to fully exploit its subsidiaries around the world. Additionally, due to the scarce resource of small business, its foreign affiliate must highly embed in local location in order to capture the necessary resources to compete with other firms.

However, some of the proposed hypotheses have not been supported by the current results. The reasons for this may lie in the specific characteristics of MNC subsidiaries in Taiwan. First, in $H 1-1$ it has been argued that through the high participation of expatriate 
subsidiary CEOs in Taiwan's local business systems, these subsidiaries acquire significant opportunities to participate in local communities. This finding contradicts prior studies that proposed the existence of a participation barrier (for example, Zaheer and Mosakowski, 1997). Second, the insignificance of H2-2 may also be attributed to the specific characteristics of MNC subsidiaries in Taiwan. Taiwan is internationally recognised as a centre of manufacturing, and hence many subsidiaries may focus on the manufacturing function to create distinctive initiatives. Third, it is thought that the insignificance of H3-1 may also lie in the attributes of MNC subsidiaries in Taiwan. Compared to previous studies focussing primarily on subsidiary initiatives in advanced countries, such as Canada, Sweden and the UK, the subsidiaries considered in this study are all located in Taiwan, whose technology and infrastructures are slightly inferior to those of advanced countries. Hence, the contents of the integration between the subsidiaries in Taiwan and other subsidiaries may be different from those identified in previous studies. However, it is acknowledged that further study is required to support this inference. To sum up, the testing results of H3-1 and H3-3 suggest that attention should be paid to the objectives, content and mechanisms of the links between the various subsidiaries of the MNC network in order to fully understand their relative influences on the subsidiary initiative.

An interesting result was found in this study. As mentioned previously, the subsidiary's integration with the MNC (H3-l) and the subsidiary's local responsiveness (H3-2) both have positive impacts on the subsidiary initiative. Although we used the similar logic (environmental stimulus, opportunities and the utilisation of resources) both in $H 3-1$ and $H 3-2$, the testing results showed that the influence of the subsidiary's local responsiveness (H3-2 is significant) is greater than the subsidiary's integration with the MNC (H3-1 is not significant). As a result, in this study, we can conclude that the local environment surrounding the subsidiary provides larger impetus for subsidiary to be initiative. On the contrary, the subsidiary's integration within the MNC provides lesser stimulus since the subsidiary in the MNC can access the similar environment and utilise same resources as other subsidiaries. Hence, 'the local differentiation', that is, the different attributes of the host country, provides the unique foundation for the subsidiary to launch its initiative.

In recent years, the topics of globalisation of small business have caught the attention of the researchers (Lu and Beamish, 2001; Manolova et al., 2002; Majocchi and Zucchella, 2003). Therefore, it is of importance to elucidate the relevance of the empirical results with regard to the globalisation strategy of small business. Due to the relatively small scale, small business must pursue a niche strategy in order to gain profits and survive in the foreign market. A niche strategy rooted in 'innovative aspect' is of paramount importance for small business's globalisation strategy because providing a 'unique benefit' to the foreign customers can overcome the disadvantages of small scale, for example, relatively high unit costs compared with large firms). As a result, this research provides some guidelines for small business to be innovative and implement a niche strategy.

First, it is obviously not enough to only utilise the 'export or license' strategy for small business to conduct its globalisation strategy. Numerous small firms start to set up their foreign subsidiaries to gain the benefits of globalisation. Owing to small scale and scarce resources, the HQ of small business tends to control tightly and leave no room for the foreign affiliate to make its own decisions. However, the positive impact of 
HQ-subsidiary procedure justice on the subsidiary initiative reveals that centralisation on subsidiary's decision power and low-consideration on the subsidiary's specific circumstance would result in decreasing the subsidiary's initiative and, hence, hampering the implementation of the niche strategy of small business. Therefore, a small business must enhance the level of procedure justice to make a foreign affiliate implementing a niche strategy successfully.

Second, since the scale of small business is small, a small firm with a niche strategy must develop its core competence in a specific area in order to compete with local firms and MNCs. The positive influence of a subsidiary's relative capabilities on its initiative demonstrates that capabilities form the foundation for innovation. Especially when a small firm competes with firms which have the advantages of large scale (for example, economies of scale and scope), it must utilise a niche strategy with highly specific capabilities to be survival and profitable in the foreign markets. For instance, many Taiwanese small businesses develop various advantages to meet these specific requirements of foreign customers in order to be successful in the global market.

Third, the positive impact of subsidiary's local responsiveness on its initiative manifests that a foreign affiliate must make endeavour in promoting its linkages with local institutions in order to compete with local firms and MNCs. On the one hand, linking with local customers and institutions can find a variety of local market opportunities and thus its is conducive to implementing a niche strategy of small business. On the other hand, due to the small scale, a small firm can cooperate with local institutions to compensate for its liability of smallness. For instance, a small firm can cooperate with local manufacturing firms to reduce its production costs, or it can cooperate with local distributions to increase its exposure to the local customers, or it can cooperate with local research agencies to enhance its innovative capability.

To sum up, a small business pursuing a globalisation strategy must find a niche to be successful. When a niche strategy is used, a small firm must enhance its procedure justice with its foreign affiliate, promote its relative capabilities and increase its local responsiveness in order to be innovative and thus successfully implement a niche strategy of globalisation.

It is recognised that this present study has some limitations. Firstly, the study has been conducted using a cross-sectional method, and accordingly, the relationships between the variables have been deduced theoretically and from the results of previous studies. The causal relationships between these variables require a longitudinal study. Secondly, the present data was collected from MNC subsidiaries in Taiwan. However, some of the variables, for example, the degree of procedural justice between the HQ and the subsidiary and the integration between the subsidiary and the MNC may be viewed differently by the HQ than by the subsidiary itself. To reduce this perception bias, future studies should collect data from both the HQ and the subsidiaries. Thirdly, although an integrated framework has been applied, it is impossible to encompass all of the related variables. Therefore, future studies should incorporate additional variables into their integrated frameworks.

There are four major topics of subsidiary initiative worthy of future study. Firstly, although the present study has examined the effects of appointing expatriates as the CEO of subsidiaries, the characteristics of the top management team have a significant influence upon organisational behaviour (Hambrick and Mason, 1984). Therefore, it is meaningful to examine the effects of the characteristics of the senior management team 
on the subsidiary initiative. For instance, does the top management team with a higher education level exhibit a higher level of subsidiary initiative? Because prior study revealed that the managers with higher education level tend to be innovative (Bantel and Jackson, 1989). Secondly, from the insignificance of H3-1, it is acknowledged that further studies on the objectives, contents and mechanisms of the links between subsidiaries are necessary if the impact of the MNC network characteristics on subsidiary behaviours is to be fully understood. Thirdly, it is worth examining the correlation between the subsidiary initiative and the subsidiary performance. Fourthly, as mentioned previously, a small business must pursue a niche strategy to implement its globalisation strategy. As the 'innovation' is the core of a niche strategy, it is extremely important to explore the determinants of a foreign subsidiary's initiatives of small business. We believe that this research provides a preliminary step on this topic.

Finally, the present findings provide some managerial implications. Firstly, developing suitable means to exploit the contributions of individual subsidiaries to promote the competitiveness of the MNC is an important issue. The HQ and subsidiary managers must consider the potential advantages to be gained from the subsidiaries and must encourage the occurrence of subsidiary initiatives. The present results have indicated that increasing procedural justice, promoting a subsidiary's capabilities, and facilitating interactions with local networks can achieve the goals of subsidiary initiative. These results can also be applied to the foreign affiliate of small business. Secondly, subsidiary managers must endeavour to promote their subsidiary's initiatives. If a subsidiary's contribution to the MNC is not continually upgraded, the HQ may withdraw its investments. Eventually, if the subsidiary is no longer perceived to add value to the MNC's operations, its very right to continued existence may be called into question.

\section{References}

Andersson, U. and Forsgren, M. (1996) 'Subsidiary embeddedness and control in the multinational corporation', International Business Review, Vol. 5, pp.487-508.

Andersson, U. and Pahlberg, C. (1997) 'Subsidiary influence on strategic behaviour in MNCs an empirical study', International Business Review, Vol. 6, pp.319-334.

Astley, G. and Zajac, E. (1990) 'Beyond dyadic exchange: functional interdependence and subunit power', Organization Studies, Vol. 11, pp.481-501.

Bantel, K.A. and Jackson, S. (1989) 'Top management and innovations in banking: does the composition of the top team make a difference?', Strategic Management Journal, Vol. 10, pp.107-124.

Birkinshaw, J. (1997) 'Entrepreneurship in multinational corporations: the characteristics of subsidiary initiatives', Strategic Management Journal, Vol. 18, pp.207-229.

Birkinshaw, J. (1998) 'Corporate entrepreneurship in network organizations: how subsidiary initiative drives internal market efficiency', European Management Journal, Vol. 16, pp.355-365.

Birkinshaw, J. and Fry, N. (1998a) 'Subsidiary initiatives to develop new markets', Sloan Management Review, Vol. 39, pp.51-61.

Birkinshaw, J. and Hood, N. (1998b) 'Multinational subsidiary evolution: capability and charter change in foreign-owned subsidiary companies', Academy of Management Review, Vol. 23, pp.773-795. 
Birkinshaw, J. and Hood, N. (1998) Multinational corporate evolution and subsidiary development, MacMillan Press Inc., London.

Birkinshaw, J. and Morrision, A.J. (1995) 'Configurations of strategy and structure in subsidiaries of multinational corporations', Journal of International Business Studies, Vol. 26, pp.729-753.

Birkinshaw, J., Hood, N. and Jonsson, S. (1998) 'Building firm-specific advantages in multinational corporations: the role of subsidiary initiative', Strategic Management Journal, Vol. 19, pp.221-241.

Birkinshaw, J. and Ridderstrale, J. (1999) 'Fighting the corporate immune system: a process study of subsidiary initiatives in multinational corporations', International Business Review, Vol. 8, pp.149-180.

Burt, R. (1992) Structural Holes the Social Structure of Competition, Harvard University Press, Cambridge.

Christmann, P., Day, D. and Yip, G.S. (1999) 'The relative influence of country conditions, industry structure and business strategy on multinational corporation subsidiary performance', Journal of International Management, Vol. 5, pp.241-265.

Damanpour, F. (1991) 'Organizational innovation: a meta-analysis of effects of determinants and moderators', Academy of Management Review, Vol. 34, pp.555-590.

Delany, E. (2000) 'Strategic development of the multinational subsidiary through subsidiary initiative-taking', Long Range Planning, Vol. 33, pp.220-244.

Dunning, J.H. (1988) 'The eclectic paradigm of international production: a restatement and some possible extensions', Journal of International Business Studies, Vol. 19, pp.1-31.

Dunning, J.H. (1995) 'Reappraising the eclectic paradigm in an age of alliance capitalism', Journal of International Business Studies, Vol. 26, pp.461-491.

Egelhoff, W.G. (1982) 'Strategy and structure in multinational corporations: an information-processing approach', Administrative Science Quarterly, Vol. 27, pp.433-458.

Floyd, S.W. and Wooldridge, B. (1999) 'Knowledge creation and social networks in corporate entrepreneur: the renewal of organisational capability', Entrepreneurship theory and practice, Vol. 23, pp.123-143.

Frost, T.S. (2001) 'The geographic sources of foreign subsidiaries' innovations', Strategic Management Journal, Vol. 22, pp.101-123.

Ghoshal, S. and Bartlett, C. (1988) 'Creation, adoption and diffusion of innovations by subsidiaries of multinational corporations', Journal of International Business Studies, Vol. 19, pp.365-387.

Ghoshal, S. and Bartlett, C. (1990) 'The multinational corporation as an inter-organizational network', Academy of Management Review, Vol. 15,pp.603-625.

Ghoshal, S. and Nohria, N. (1989) 'Internal differentiation within multinational corporations', Strategic Management Journal, Vol. 10, pp.323-337.

Glynn, M.A. (1996) 'Innovative genius a framework for relating individual and organizational intelligences to innovation', Academy of Management Review, Vol. 21, pp.1081-1111.

Goes, J.B. and Park, S.H. (1997) 'Interorganizational links and innovation: the case of hospital services', Academy of Management Journal, Vol. 40, pp.673-696.

Gupta, A.K. and Govindarajan, V. (1991) 'Knowledge flows and the structure of control within multinational corporations', Academy of Management Review, Vol. 16, pp.768-792.

Gupta, A.K. and Govindarajan, V. (1994) 'Organizing for knowledge flows within MNCs', International Business Reviews, Vol. 3, pp.443-457.

Gupta, A.K. and Govindarajan, V. (2000) 'Knowledge flows within multinational corporations', Strategic Management Journal, Vol. 21, pp.473-496. 
Hair, J.F., Andersson, R., Tatham, R.L. and Black, W.C. (1995) Multivariate Data Analysis, Fourth Edition, Englewood Cliff, Prentice Hall, New Jersey.

Hambrick, D.C. and Mason, P.A. (1984) 'Upper echelons: the organisation as a reflection of its top managers', Academy of Management Review, Vol. 9, pp.193-206.

Hannon, J.M., Huang, I.C. and Jaw, B.S. (1995) 'International human resource strategy and its determinants: the case of subsidiaries in Taiwan', Journal of International Business Studies, Vol. 26, pp.531-554.

Hedlund, G. and Rolander, D. (1990) 'Action in heterarchies: new approaches to managing the MNC', in Bartlett, C.A., Doz, Y. and Hedlund, G. (Eds.): Managing the Global Firm, Routledge and Kegan Paul, London and New York.

Hennart, J.-F. (1993) 'Control in multinational firms the role of price and hierarchy', in Ghoshal, S. and Westney, D.E. (Eds.): Organization theory and the multinational cooperation, St. Martin's Press, New York.

Holm, U., Johanson, J. and Thilenius, P. (1995) 'Headquarters' knowledge of subsidiary network contexts in the multinational corporation', International Studies of Management and Organization, Vol. 25, pp.97-119.

Jarillo, J.C. and Martinez, J.I. (1990) 'Different roles for subsidiaries: the case of multinational corporations in Spain', Strategic Management Journal, Vol. 11, pp.501-512.

Kim, W.C. and Mauborgne, R. (1993a) 'Effectively conceiving and executing multinational's worldwide strategies', Journal of International Business Studies, Vol. 24, pp.419-448.

Kim, W.C. and Mauborgne, R. (1993b) 'Procedural justice, attitudes and subsidiary top management compliance with multinational's corporate strategic decisions', Academy of Management Journal, Vol. 36, pp.502-526.

Lu, J.W. and Beamish, P.W. (2001) 'The internationalisation and performance of SMEs', Strategic Management Journal, Vol. 22, pp.565-586.

Majocchi, A. and Zucchella, A. (2003) 'Internationalization and performance', International Small Business Journal, Vol. 21, pp.249-266.

Manolova, T.S., Brush, G.B., Edelman, L.F. and Greene, P.G. (2002) 'Internationalisation of small firms', International Small Business Journal, Vol. 20, pp.9-29.

Moore, K. and Birkinshaw, J. (1998) 'Managing knowledge in global service firms centers of excellence', Academy of Management Review, Vol. 12, pp.81-92.

Nobel, R. and Birkinshaw, J. (1998) 'Innovation in multinational corporations: control and communication patterns in international R\&D operations', Strategic Management Journal, Vol. 19, pp.479-496.

Nunnally, J.C. (1978) Psychometric Theory, NY: McGraw-Hill, New York.

Pearce, R. (1999) 'The evolution of technology in multinational enterprises: the role of creative subsidiaries', International Business Review, Vol. 8, pp.125-148.

Perlmutter, H.V. (1969) 'The tortuous evolution of the multinational corporation', Columbia Journal of World Business, Vol. 4, pp.9-18.

Porter, M.E. (1990) The Competitive Advantage of Nations, The Free Press, New York.

Prahalad, C.K. and Doz, Y.L. (1981) 'An approach to strategic control in MNCs', Sloan Management Review, Vol. 22, pp.5-13.

Roth, K. and Morrison, A.J. (1990) 'An empirical analysis of the integration-responsiveness framework in global industries', Journal of International Business Studies, Vol. 21, pp.541-564.

Roth, K. and Morrison, A.J. (1992) 'Implementing global strategy: characteristics of global subsidiary mandate', Journal of International Business Studies, Vol. 23, pp.715-735. 
Rugman, A.M. and Verbeke, A. (2001) 'Subsidiary-specific advantages in multinational enterprises', Strategic Management Journal, Vol. 22, pp.237-250.

Russell, R.D. (1999) 'Developing a process model of intrapreneurial system: a cognitive mapping approach', Entrepreneurship Theory and Practice, Vol. 23, pp.65-85.

Stopford, J.M. and Wells, L.T. (1972) Managing the multinational enterprise, Basic Books, New York.

Taggart, J.M. (1997) 'An evaluation of integration-responsiveness framework: MNC manufacturing subsidiaries in the UK', Management International Review, Vol. 37, pp.295-318.

Taggart, J.M. (1998) 'Strategy shifts in MNC subsidiaries', Strategic Management Journal, Vol. 19, pp.663-681.

Teece, D.J., Pisano, G. and Shuen, A. (1997) 'Dynamic capabilities and strategic management', Strategic Management Journal, Vol. 18, pp.509-533.

Tsai, W. and Ghoshal, S. (1998) 'Social capital and value creation the role of intrafirm networks', Academy of Management Journal, Vol. 41, pp.464-476.

Woodman, R. W., Sawyer, J.E. and Griffin, R.W. (1993) 'Toward a theory of organizational creativity', Academy of Management Journal, Vol. 18, pp.293-321.

Zaheer, S. and Mosakowski, E. (1997) 'The dynamics of the liability of foreignness: a global study of survival in financial services', Strategic Management Journal, Vol. 18, pp.439-464.

Zahra, S.A. (1991) 'Predictors and financial outcomes of corporate entrepreneurship: an exploratory study', Journal of Business Venturing, Vol. 6, pp.259-285.

\section{Notes}

1 Birkinshaw and Hood (1998b) used the title 'subsidiary's role' in their subsidiary research classification. However, this paper adopts the term 'The network characteristics of a subsidiary within the MNC network' to emphasise the characteristics of a subsidiary embedded in an MNC network.

2 This study focusses on just three important value chain activities, namely, $R \& D$, manufacturing and marketing (including sales and logistic distribution).

\section{Appendix 1 The basic characteristics of research sample*}

\begin{tabular}{|c|c|c|c|}
\hline Subsidiary's age & \multicolumn{3}{|c|}{19.81 years } \\
\hline Subsidiary's scale & \multicolumn{3}{|c|}{477 employees } \\
\hline Subsidiary's nationality & US: 25 & 25 & Europe: 17 \\
\hline \multirow[t]{2}{*}{ Subsidiary's industry } & $\begin{array}{l}\text { Electronics and information- } \\
\text { related industries }\end{array}$ & $\begin{array}{r}\mathrm{Pl} \\
\text { chen }\end{array}$ & $\begin{array}{l}\text { rrmaceutical, plastics, } \\
\text { istry, textile, or logistics } \\
\text { industries }\end{array}$ \\
\hline & 35 & & 32 \\
\hline Whether or not the subsidiary & Yes & & No \\
\hline $\begin{array}{l}\text { Perform the manufacturing } \\
\text { operation }\end{array}$ & 49 & & 18 \\
\hline
\end{tabular}

Note: $\quad *$ total number of the sample is 67 
Appendix 2 Descriptive statistics and correlation tables ${ }^{1,2}$

\begin{tabular}{|c|c|c|c|c|c|c|c|c|c|}
\hline Variables & Reliability & 2 & 3 & 4 & 5 & 6 & 7 & 8 & 9 \\
\hline 1 Industry integration & 0.8480 & -0.055 & 0.085 & 0.132 & $0.385 * * *$ & $0.372 * *$ & $0.412 * * *$ & $0.325^{* *}$ & 0.117 \\
\hline 2 Subsidiary age & - & & -0.044 & $0.257^{*}$ & $-0.235^{*}$ & 0.080 & 0.025 & -0.028 & 0.042 \\
\hline 3 Subsidiary scale & - & & & -0.080 & 0.083 & $0.219 *$ & 0.104 & 0.173 & 0.014 \\
\hline 4 HQ control equity & - & & & & -0.004 & $0.210^{*}$ & $0.260 *$ & -0.168 & 0.039 \\
\hline 5 Procedural justice & 0.8532 & & & & & $0.343^{* *}$ & $0.212^{*}$ & $0.395^{* * *}$ & 0.089 \\
\hline $\begin{array}{l}6 \text { Subsidiary } \\
\text { capability }\end{array}$ & 0.8132 & & & & & & 0.054 & $0.482 * * *$ & $0.339 * *$ \\
\hline 7 Integration & 0.9122 & & & & & & & 0.070 & -0.040 \\
\hline $\begin{array}{l}8 \text { Local } \\
\text { responsiveness }\end{array}$ & 0.7213 & & & & & & & & 0.089 \\
\hline 9 Non-substitutability & 0.8492 & & & & & & & & \\
\hline
\end{tabular}

Notes: $\quad * \mathrm{p}<.05 ; * * \mathrm{p}<.01 ; * * * \mathrm{p}<.001$

${ }^{1}$ Only continuous-type variables are included in this table

${ }^{2}$ The reliability of subsidiary initiative is .7578

The mean and standard deviation of each variable (standard deviation value is in parenthesis)

Industry integration: 26.38 (5.23) Subsidiary age: 19.81 (11.24) Subsidiary scale: $3.78(0.88)$

HQ control equity: 84.72 (20.55) Procedure justice: 23.07 (6.32) Subsidiary capability: 22.88 (5.77)

Integration:25.24 (7.33) Local responsiveness:22.97 (5.64)

Non-substitutability:14.33 (5.94) 